\title{
Application of Immunocytochemistry to Sputum Cells to Investigate Molecular Mechanisms of Airway Inflammation
}

\author{
Kittipong Maneechotesuwan and Adisak Wongkajornsilp \\ Faculty of Medicine Siriraj Hospital, \\ Mahidol University \\ Thailand
}

\section{Introduction}

The definition of sputum is not equivalent to mucus, but sometime clinicians use both interchangeably. The definition includes the pathological secretion dispelled by cilia and expectorated with coughing. It maintains airway hydration and traps particulates, bacteria, and viruses.

The contents of sputum comprise damaged ciliated epithelium and inflammatory cells. Airway mucus possesses antioxidant, antiprotease, and antimicrobial activities. Its volume is increased during chronic airway inflammation. The sputum composition can be altered by the underlying disease and its severity. The expansion of sputum neutrophil is variably in severe asthma or in chronic obstructive pulmonary disease (COPD).

Cough and ciliary clearance greatly depend on the viscosity of the secretion to the ciliary surface (Voynow \& Rubin 2009). Surface tension and surfactant interactions can overpower surface forces. Tenacity or adhesivity is the greatest determinant for the efficiency of cough to eliminate secretion (Voynow \& Rubin 2009).

Sputum analysis is a non-invasive approach to dissect underlying pathophysiology of inflammatory airway diseases. The cellular and biochemical constituent of sputum correlates well with both bronchial wash (BW) and bronchoalveolar lavage (BAL), but to a lesser degree with bronchial biopsies (Fahy, et al. 1995, Pizzichini, et al. 1998, Maestrelli, et al. 1995). These observations imply the differences in the luminal and mucosal phase of airway inflammation. The fraction of neutrophils decreases from central (20-30\%) to peripheral airways $(<2 \%)$ while the opposite is true for macrophages (Rankin, et al. 1992). Based on this observation, sputum represents the more proximal airway, whereas BW and BAL represent the more peripheral airways. Successive sputum collection after a single sputum induction exhibited a stepwise neutrophil decrement and macrophage increment (Holz, et al. 1998a, Richter, et al. 1999) reflecting the sampling of more distal airway from later collection. The standardization of sputum induction is required to reduce inter- and intra-subject variability. 


\section{Sputum induction}

The sputum induction technique allows the noninvasive collection of the airway content and provides an opportunity to identify biomarkers of airway inflammation in several conditions (e.g., asthma and COPD). It is superior to spontaneous sputum expectoration in the higher quantity of collected secretion from the lower airways. Sputum induction requires a high degree of cooperation from the patient. The procedure should be performed in a quiet environment and conducted by an experienced technician under the supervision of an experienced physician.

Ultrasonic neubulizers are recommended for sputum induction since other nebulizers do not provide the sufficient output of saline aerosol. The output of nebulizers should be accurately tested. A spirometry provides real-time assessment of the baseline airway caliber and promptly alerts for the excessive bronchoconstriction during the saline induction (Paggiaro, et al. 2002). A spirometer is superior to a peak flow meter since it provides greater sensitivity to measure the decline in force expiratory volume in one second $\left(\mathrm{FEV}_{1}\right)$ that alludes to saline-induced bronchoconstriction. Oxygen saturation should be monitored if there is any suspicion of resting hypoxemia. Oxygen supplement should be in reach for COPD patients with hypoxemia exacerbation (Paggiaro et al. 2002).

Sterile saline solution should be freshly prepared. Rescuing medications, bronchodilator (inhaled or nebulized salbutamol or other $\beta_{2}$-agonists) (Paggiaro et al. 2002) and other resuscitation medicines must be nearby. Sputum induction should be performed under aseptic environment. Hypertonic saline can induce bronchoconstriction in asthmatics (Smith \& Anderson 1989) with unknown mechanism, possibly through the activation of mast cells (Gravelyn, et al. 1988) or sensory nerve endings (Makker \& Holgate 1993).

The pretreatment with a short-acting $\beta_{2}$-agonists is recommended as the standard protocol to prevent excessive bronchoconstriction (Pin, et al. 1992, Wong \& Fahy 1997, Jatakanon, et al. 1998) that could pose asthmatics at risk of an exacerbation. Excessive bronchoconstriction might bring about the premature termination of the induction resulting in an inadequate sputum collection. Salbutamol (200-400 $\mu \mathrm{g}$ or 2-4 puffs from a metered dose inhaler) can be used for pretreatment. Pretreatment with higher doses of salbutamol cannot provide additional advantage for the prevention of hypertonic saline-induced bronchoconstriction (Wong \& Fahy 1997, Cianchetti, et al. 1999, de la Fuente, et al. 1998, Peleman, et al. 1999), but may induce more severe subsequent bronchoconstriction. Therefore, a single dose of salbutamol $200 \mu \mathrm{g}$ is recommended both before and after the measurement of $\mathrm{FEV}_{1}$ for 10 min. Salbutamol pretreatment does not interfere the inflammatory cell percentage in induced sputum (Cianchetti et al. 1999, Popov, et al. 1995). Regarding the effects on soluble mediators in sputum supernatant, salbutamol has no effect on eosinophil cationic protein (ECP) levels, but tends to reduce histamine concentrations (Cianchetti et al. 1999). There has been no study for the effect of salbutamol on the levels of other soluble mediators (i.e., cytokines, albumin, and neutrophil elastase) or the expression of cell activation markers as detected by immunocytochemistry. Also, the data on the comparison between different bronchodilators ( $\beta_{2}$-agonists and anticholinergic drugs) are not available.

Monitoring pulmonary function during sputum induction is indispensable for safety precaution. However, no standardized monitoring protocol for pulmonary function has been recommended. Most studies measure $\mathrm{FEV}_{1}$ every 5-10 min, with additional 
measurement if any symptom develops (Iredale, et al. 1994, Bacci, et al. 1998, Pin et al. 1992, Jatakanon et al. 1998, Wong \& Fahy 1997, Maestrelli, et al. 1994). Since poor perception of dyspnea can exist while bronchospasm can occur early, the measurement of pulmonary function within the first minute of nebulization should be performed to identify supersensitive subjects. $\mathrm{FEV}_{1}$ should be periodically monitored with an interval of $\leq 5 \mathrm{~min}$ during aerosol inhalation. A single measurement is appropriate if the change in $\mathrm{FEV}_{1}$ is < $10 \%$ of the postbronchodilator $\mathrm{FEV}_{1}$ value.

\subsection{Selecting saline concentrations}

The concentrations of saline solution for sputum induction varied from $0.9 \%$ to $7 \%$ in different studies. Some investigators raised the concentration in a stepwise manner $(3 \%, 4 \%$ and $5 \%$ ) during sputum induction. Saline concentration and nebulizer output might influence the safety, tolerability and success rate of the induction as well as the cellular and biochemical constituents. The $3 \%$ hypertonic saline achieved the same success rate as $3-5 \%$ given sequentially. Hypertonic saline solutions are more effective than isotonic saline for sputum induction. The latter should be reserved for patients at high risk of bronchoconstriction. There is a consensus to advocate sputum induction with $4.5 \%$ sodium chloride solution that is commercially available.

Hypertonic or isotonic saline did not elicit any significant alteration in cellular ratio or their quantity in the sputum. However, the concentration-effect relationship between different saline concentrations and the levels of most soluble mediators in the sputum supernatants remain unknown. There is no difference in the levels of ECP and histamine in the sputum supernatant induced by isotonic or hypertonic saline (Bacci, et al. 1999). Sputum supernatant osmolarity fluctuates between $70-360 \mathrm{mOsm}$ as a result of the natively high variation in sputum concentrations of sodium, chloride and magnesium from individual subjects.

\subsection{Selecting nebulizer}

The selection of nebulizer based on type and output is important for the attainment of sputum induction. The ultrasonic nebulizer offers higher success rates than does jet nebulizer (Popov et al. 1995). The exact volume of inhaled saline solution that might be required to induce an adequate sputum sample is still unclear. The optimal duration of inhalation and the optimal output are also unclear. Longer duration might yield samples from more distal airways. Other factors include the size of aerosols and their deposited locations. The deposition at different locations might yield different sputum composition and success rates. The common practice employing ultrasonic nebulizer with an output of $\sim$ $1 \mathrm{~mL} / \mathrm{min}$ can achieve a satisfactory quantity.

\subsection{Duration of nebulization}

Duration of nebulization can influence the cellular components of the resulting sputum. At the early phase (0-4 min), neutrophils, eosinophils and mucin are major components in the sputum. At the later phase $(16-20 \mathrm{~min})$, lymphocytes, macrophages and surfactant are increasingly noticeable (Holz et al. 1998a, Gershman, et al. 1999). This pattern suggests that central airways are sampled at the early phase, whereas peripheral airways and alveoli are 
sampled at the later phase. The early-phase sputum may be discarded to avoid the saliva contamination. Subsequent samples may be more suitable for the analysis. Although the maximal duration of induction has not been properly studied, it depends on the conciliation between the success rate and the tolerability/safety. Shorter inhalation times (e.g. 15-20 min) have similar success rates and practicability to longer inhalation times (30 min). It is critical to keep the duration of inhalation constant between inductions in the same subject to obtain comparable results. Common practice employs a cumulative duration of nebulization for 15$20 \mathrm{~min}$. Other influencing factors might include the respiratory frequency during nebulization and the patterns of inhalation (i.e., slow deep inhalation or tidal breathing) during the challenge.

\subsection{Variations of expectoration}

Some investigators recommend that subjects clean their oral cavity with gargle, dry with napkin, spit for saliva, and finally cough for sputum. Others argue that mouth rinsing and drying may increase oropharyngeal inflammation. Some authors encourage the use of nose clips. Sputum induction protocols are different with respect to the schedule of sputum collection. Subjects may be asked to stop inhalation at regular intervals to cough up sputum (e.g., every $5 \mathrm{~min}$ ), or to stop only when they feel the urge to cough. Some protocols require subjects to spit saliva into one container before coughing sputum into the other. Spitting saliva before coughing sputum decreases the percentage of squamous cells in sputum by $30 \%$ and increases ECP in the supernatant by $80 \%$ (Gershman, et al. 1996). The production of a good sputum sample relies heavily on the characteristics of the individual subject rather than the technical factors.

\subsection{Repeating sputum induction}

Repeated sputum induction can heighten airway inflammation resulting in an iatrogenic change in cellular components. Repeating sputum induction at 8-24 $\mathrm{h}$ after the initial induction can increase neutrophil recruitment in the second sputum sample (Nightingale, et al. 1998, Holz, et al. 1998b). An interval of $48 \mathrm{~h}$ between two inductions gave comparable cell counts in normal subjects (Purokivi, et al. 2000). It is currently recommended that subsequent induction should be conducted at least 2 days apart.

\subsection{Sputum induction protocols}

\subsubsection{Classical procedure}

1. The detailed information should be provided to the patient prior to the procedure.

2. All equipments including the ultrasonic nebulizer should be checked for safety and calibrated for the output of $\sim 1 \mathrm{~mL} / \mathrm{min}$.

3. The baseline $\mathrm{FEV}_{1}$ is measured prior to the bronchodilator inhalation.

4. The bronchodilator $(200 \mu \mathrm{g}$ salbutamol) is inhaled before the commencement of sputum induction.

5. The $\mathrm{FEV}_{1}$ is measured after the bronchodilator inhalation for $10 \mathrm{~min}$.

6. Either a fixed concentration ( 3 or $4.5 \%)$ or increasing gradient $(3,4$ and $5 \%)$ of sterile saline is nebulized as an inducer. Each nebulization lasts $5 \mathrm{~min}$ follows by a brief expectoration. The total duration will last $\leq 20 \mathrm{~min}$. Alternatively, the continuous 20- 
min nebulization may be interrupted at 1, 4, 5, 10, 15, and 20 min for expectoration. The subjects will be allowed to spit outside the schedule whenever they develop the urge to cough.

7. The $\mathrm{FEV}_{1}$ at each interruption will be measured. The induction will be terminated if there is $\geq 20 \%$ fall in $\mathrm{FEV}_{1}$ from the postbronchodilator value or the symptoms develop.

\subsubsection{Customized procedure for high-risk subjects}

1. The detailed information should be provided to the patient prior to the procedure.

2. All equipments including the ultrasonic nebulizer should be checked for safety and calibrated for the output of $\sim 1 \mathrm{~mL} / \mathrm{min}$.

3. The baseline $\mathrm{FEV}_{1}$ is measured prior to the bronchodilator inhalation.

4. The bronchodilator $(200 \mu \mathrm{g}$ salbutamol) is inhaled before the commencement of sputum induction.

5. The $\mathrm{FEV}_{1}$ is measured after the bronchodilator inhalation for $10 \mathrm{~min}$.

6. The $0.9 \%$ sterile saline solution will be nebulized with interruptions at $30 \mathrm{sec}, 1$, and 5 min for $\mathrm{FEV}_{1}$ measurement as a safety precaution. If this fails to induce sputum, the $3 \%$ saline concentration will be nebulized with interruptions at $30 \mathrm{sec}, 1$, and $2 \mathrm{~min}$ for $\mathrm{FEV}_{1}$ measurement. If this also fails to induce sputum, the $4.5 \%$ saline concentration will be nebulized with interruptions at $30 \mathrm{sec}, 1,2,4$ and $8 \mathrm{~min}$ for $\mathrm{FEV}_{1}$ measurement. The induction will be terminated if there is $\geq 20 \%$ fall in $\mathrm{FEV}_{1}$ from the postbronchodilator value or the symptoms develop.

7. If the subjects cannot produce spontaneous cough, they will be driven to cough and spit after 4 and 8 min.

\subsection{General consideration}

1. The protocol should be strictly enforced, especially the inhalation timing.

2. The induction should not be repeated within $48 \mathrm{~h}$ after the first induction.

3. The safety procedure must be ensured and readily accessible.

\subsection{Validation of sputum}

The outcome of downstream application relies on the quality of sputum. The procurement of secretions from the lower respiratory tract (sputum) induced by the inhalation of aerosol from hypertonic saline usually is contaminated with saliva. The assessment of sputum quality relies on the quantitation of contaminated squamous epithelial cells.

The collection method has been optimized to improve the induced sputum quality by the selection of viscous portion of the specimen that should minimize the contamination with squamous epithelial cells (Pizzichini, et al. 1996b). This selective collection could obtain at least two-thirds of the viable nonsquamous cells. After DTT treatment, the cellular contents of the selectively collected sample would be dispersed and were ready for cytospin examination. This selected portion usually held a similar proportion of neutrophils, eosinophils and lymphocytes. However, it contained much higher concentrations of the fluid-phase ECP than did the whole expectoration. The unaltered cellular proportion suggested that the selection for viscous portion did not alter the indices of airway inflammation. Normally, saliva contains mainly squamous epithelial cells (99\%) but very 
low levels of ECP (2-90 ng/mL). The selected viscous portion was generally contaminated with very little squamous cells $(1.2 \%)$, whereas the remaining clear portion contained a large portion of squamous cells (70\%) (Pizzichini et al. 1996b). The lessening squamous cell content unmasked the inflammatory cells, resulting in better quality after the cytospins. When the squamous contamination was less than $20 \%$, the accuracy of differential cell counts was better, as indicated by high inter and intraobserver reproducibility. The processing of cytospin is also quicker, especially when 1,000 or so cells were counted for more accurate identification of metachromatic cells and lymphocytes, the minority cellular contents. Also, the small proportion of squamous cells provides a homogeneous population of cells for examination by flow cytometry (Kidney, et al. 1996).

Alternatively, the quality of induced sputum specimen can be evaluated by the presence of high proportion of viable nonsquamous cells. Cell viability is an important requirement for accurate cell identification. With greater than $50 \%$ viability, the reproducibility of cell counts is better. Higher viability also provided an advantage for immunological staining to determine subpopulations and activation markers (Hansel, et al. 1991, Kidney et al. 1996, Vatrella, et al. 2010).

In summary, the physical selection of viscous portion from the mixed expectorate has several advantages over the whole specimen. It is almost free of squamous cells and is therefore essentially undiluted. Cells are in better condition and the concentrations of eosinophilic cationic protein are higher. If the expectorate is not processed within $2 \mathrm{~h}$, a large error might be introduced. The serous portion, which is rich in squamous cells, could be homogeneously mixed with the otherwise desirable viscous portion. The reproducibility of cell counts is threatened if squamous cell contamination represents $>20 \%$ of all recovered cells.

\section{The conventional practice for cytologic study}

The sputum should be processed as soon as possible or within $2 \mathrm{~h}$ to ensure optimal cell counting and staining (Pizzichini et al. 1996b, Fahy, et al. 1993). The dithiothreitol (DTT) is used to split the disulfide bonds in mucin to release the cells (Cleland 1964). Cells anchoring to the mucus tend to get dark stain that hinders accurate identification. DTT provides more effective cellular liberation from the mucus than does phosphate buffered saline (PBS) and has no effect on cell counts.

The duration and temperature of mixing can vary between $10-30 \mathrm{~min}$ and $4-37^{\circ} \mathrm{C}$ respectively. This range of DTT exposure time at room temperature has no effect on the differential cell count (Popov, et al. 1994). The mixing of sputum with DTT can be performed with either a shaking water bath at $37^{\circ} \mathrm{C}$ followed by periodic aspirations, or a tube rocker at $22^{\circ} \mathrm{C}$ (Popov et al. 1994, Fahy et al. 1993, Spanevello, et al. 1998). The use of a plastic transfer pipette for aspiration and expulsion of sputum is not recommended since it decreases cell yield due to incomplete mixing (Popov et al. 1994, Hansel et al. 1991).

A sample filtration is strongly recommended for removing residual mucus and debris to improve slide quality. A single filtration through a $48-\mu \mathrm{m}$ nylon mesh results in a slight reduction in the total cell count but the differential cell count remains unchanged (Efthimiadis, et al. 1996, Efthimiadis, et al. 2000). However, little is known about the effect of repeated filtrations on differential cell count. 
Since the total cell count could be lessened after centrifugation (Parameswaran, et al. 2000, Rerecich, et al. 1999), it is therefore recommended that total cell count be performed prior to centrifugation to exactly obtain the original cell count. The currently automated machine is not reliable for determining total cell count and differential cell count, and is still not recommended.

Centrifugation is generally used to separate sputum cells from the fluid phase. The centrifugation force should be set between $300-1500 \times \mathrm{g}$ for 5-10 min to obtain adequate separation of the cells and the supernatant (Fahy et al. 1993, Louis, et al. 1999, Pizzichini, et al. 1996a). The storage temperatures for cells and supernatants are $-20^{\circ} \mathrm{C}$ and $-70^{\circ} \mathrm{C}$ respectively (Pizzichini et al. 1996a).

The optimum cell density for cytospins is $40-60 \times 10^{3}$ cells / slide that provide a more accurate estimate for cell distribution than does the smearing technique (Pizzichini et al. 1996a, Popov et al. 1994). The centrifugation force of $22 \times \mathrm{g}$ for $6 \mathrm{~min}$ is generally employed (Pizzichini et al. 1996a, Popov et al. 1994). Although this speed is below the limits of minimal cell distortion, there is a risk of losing lymphocytes at low speeds due to the dispersion to the supernatant (Fleury-Feith, et al. 1987, Mordelet-Dambrine, et al. 1984). This should be taken into account in the investigations of sputum lymphocytes.

The differential cell counts can be accomplished using either Wright's or Giemsa stain (Efthimiadis, et al. 2002). The buffers must be titrated to the optimal pH (7.1-7.2) (Efthimiadis et al. 2002) to allow accurate characterization of cells based on their optimal staining while maintaining original morphology. The differential cell count requires a minimum of 400 nonsquamous cells (Efthimiadis et al. 2002). The report should contain the relative numbers of eosinophils, neutrophils, macrophages, lymphocytes and bronchial epithelial cells expressed as a percentage of total nonsquamous cells. The percentage of squamous cells should always be reported separately.

\section{Immunocytochemistry procedures}

The sputum suspension is centrifuged at $300 \times \mathrm{g}$ for $10 \mathrm{~min}$, resuspended in PBS or Hank's balance saline solution (HBSS). The cytospins are prepared on L-polylysine-coated slides to ensure minimal cell loss during multiple washing steps. The attached cells are air-dried for $10 \mathrm{~min}$ and fixed appropriately. After fixation, cytospins should be wrapped in foil and stored at $-20^{\circ} \mathrm{C}$ pending for staining.

The method of fixation is critical and needs to be optimized for any particular antigen to obtain the best quality of immunostaining. The selected fixation method should allow the proper preservation of antigens / cellular morphology and the penetration of antibodies into the entire cells. The fixation regimens may include either 2 or $4 \%$ paraformaldehyde, formalin, acetone/methanol (60/40) or periodate-lysine-paraformaldehyde (PLP). The latter is a fixative for surface glycoprotein staining but may also be used for cytokine staining (McLean \& Nakane 1974). For instance, PLP fixation provided better morphology of cryostat sections but poorer immunostaining than conventional acetone immersion. However, a brief acetone fixation followed by PLP fixation offered excellent morphology preservation and good quality of immunostaining (Hall, et al. 1987). PLP was proposed for the fixation of multiple membrane antigens in skin biopsies (Pieri, et al. 2002). The benefit of PLP fixation is in the preservation of cellular ultrastructures (i.e., immunoglobulins) for 
immunofluorescence or immunoperoxidase staining of paraffin-embedded specimens (Rantala, et al. 1985). For marker staining of induced sputum cells, PLP-sucrose provided the best results with the highest percentage of $\mathrm{CD}^{+}$cells and a better staining quality than did the paraformaldehyde and acetone-methanol-fixed cells that provided the worst staining of CD68 (St-Laurent, et al. 2006). Simultaneous fixation and permeabilization using Ortho PermeaFix for flow cytometry are required for the best identification of intracellular antigens (i.e., eosinophil cationic protein, eosinophilic peroxidase, neutrophil myeloperoxidase) in cytocentrifuged cells (Metso, et al. 2002). Organic solvents as fixatives are not suitable while the crosslinking fixatives (e.g., paraformaldehyde) alone could not provide a complete penetration of antibodies into the cell interior (Metso et al. 2002).

To detect intracellular antigens, sputum cells must be permeabilized after the fixation with paraformaldehyde and glutaraldehyde. Permeabilization allows the antibody to gain an access to intracellular or intraorganellar antigens. Two common permeabilizing agents are organic solvents (i.e., methanol and acetone) and detergents.

The organic solvents work through dissolving lipids from cell membrane, thereby disrupting the membrane and allowing the influx of the antibodies. The ability of the organic solvents to coagulate proteins provides an additional advantage of cell fixation. The shortcoming of organic solvents is the removal of lipidic antigens or lipid associated antigens from cells.

One of the most commonly used detergents is saponin, a plant glycoside. Saponin permeabilizes cells through the removal of cholesterol, thereby puncturing holes over the membrane (Seeman, et al. 1973). Saponin can form micelle with antibody and cholesterol that facilitates the entry through the punctured holes. However, saponin cannot effectively permeabilize mitochondrial membranes and the nuclear envelope due to their low composition of cholesterol (Goldenthal, et al. 1985a). Therefore, saponin is suitable for immunostaining of intracellular membrane antigens localized over lysosomal membrane, plasma membrane, endocytic vesicles and endoplasmic reticulum (Goldenthal, et al. 1985b). However, Triton X-100 and NP-40 interfere the staining at these sites (Goldenthal et al. 1985b).

Other commonly used detergents are the non-ionic detergents such as Triton X-100 and Tween 20 (Maneechotesuwan, et al. 2010, Maneechotesuwan, et al. 2008). They carry uncharged, hydrophilic head groups of polyoxyethylene moieties. Antigens localized in mitochondria and the nucleus required Triton X-100 for their detection (Goldenthal et al. 1985b). Their shortcoming is their non-selective nature that could produce a false negative during immunostaining through the removal of proteins along with the lipids. A combination of different permeabilizing agents may be customized for each antigen (Goldenthal et al. 1985a).

Immunocytochemical staining can be performed with different varieties, including avidin/biotin complex, peroxidase/antiperoxidase and alkaline phosphatase / antialkaline phosphatase techniques. The use of immunoenzymatic techniques eliminates the need for expensive fluorescent microscopy. The alkaline phosphatase / antialkaline phosphatase method is preferable. The staining with the monoclonal antibodies on fixed slides should be titrated for appropriate concentrations and can be incubated overnight at $4^{\circ} \mathrm{C}$. The secondary antibodies are then applied and the antibody/antigen complex is visualized 
using the alkaline-phosphatase-linked substrate, with either fast red or fast blue counterstains. Negative controls must always be included to exclude the potential false positive staining. The peroxidase staining methods are not recommended for sputum.

\section{Modifications of immunocytochemistry for sputum specimen}

Homogenization with low-concentration DTT $(0.5 \mathrm{mM})$ would liberate the otherwise anchored cells from the surrounding mucus that facilitate the exposure of the cells to the staining antibodies (Tockman, et al. 1995). However, the use of DTT to disperse cells may hamper cellular functions (e.g., the release of elastase and myeloperoxidase (MPO) from neutrophils (van Overveld, et al. 2005)) or hinder antigenic epitopes for immunocytochemical staining. Some investigators recommended the use of paraformaldehyde to fix the sputum cells prior to the treatment with low concentration of DTT.

The method employing avidin-biotin complex (ABC) is suitable for the immunocytochemistry of sputum cells (Maneechotesuwan et al. 2008, Maneechotesuwan et al. 2010). The biotin / avidin system possesses several advantages to sputum immunocytochemistry. 1) The binding affinity of avidin to biotin is higher than that of any antibody directing against its epitope. 2) The binding of avidin to biotin is almost irreversible. 3) The multiple binding sites on each molecule (four binding sites for biotin on each avidin; two binding sites for avidin on each biotin) provide the formation for macromolecular complexes between avidin and biotinylated enzymes. The ABC-alkaline phosphatase (AP) lattice complex consists of several biotinylated alkaline phosphatase molecules cross-linked by avidin. The two biotin molecules can be joined via an avidin molecule that eventually forms a complex of avidin and biotinylated enzyme or biotinylated secondary antibody. The stoichiometry of the forming complex will contain an available biotin binding site on $\mathrm{ABC}$ for the binding of the biotinylated secondary antibody. The formation of the complex is developed by gradual mixing avidin and biotinylated alkaline phosphatase with predefined ratios prior to use. The ABC complex can be stable until $24 \mathrm{~h}$ after the formation. This technique provides multiple enzymes attaching to the antigenic site, thereby enhancing the detection sensitivity. The sensitivity provided by this method is generally higher than that obtained with the conventional peroxidase-anti-peroxidase (PAP) technique. However the size of the $\mathrm{ABC}$ complex can be inappropriately high that it sterically interferes the overall binding, resulting in decreasing the resolution.

The $A B C$ method can also be modified to incorporate different enzymes that provide different chromogenic properties (Bratthauer 2010). These enzymes include alkaline phosphatase (AP). The high sensitivity of the ABC-AP system permits the detection of the small amount of antigen using higher dilution of a primary antibody. Therefore, the ABCAP system is recommended for staining situation in which high sensitivity is a prerequisite such as sputum immunocytochemistry. The advantages of these techniques lie in the availability of suitable secondary agents. The shortcoming of this system is the presence of endogenous alkaline phosphatase, which is more ubiquitous than endogenous peroxidase and is tougher to remove. However, the alkaline phosphatase can generate more color producing molecules per enzyme molecule than can peroxidase, resulting in higher sensitivity. Endogenous alkaline phosphatase can be partially blocked by incubation with $3 \mathrm{mM}$ levamisole for $15 \mathrm{~min}$ with some remaining residual activity. 
Labeling of 2 epitopes can employ the simultaneous peroxidase and AP methods. An ABC assay system can be applied to the detection of more than one antibody on an individual specimen. In double labeling, experiments having two completely different assay systems would minimize the cross-over reactivity. The first antigen can be detected with the standard $\mathrm{ABC}$ procedure, while the second antigen can be detected using the PAP system. The two techniques provide minimal cross-over reactivity, especially if alkaline phosphatase is employed along with the peroxidase enzyme (Gillitzer, et al. 1990).

Various sugar moieties interfere with the binding of streptavidin or avidin to biotin. The most effective inhibitory sugar is mannose, followed by other saccharides. The inhibitory action probably involves the interactions of the sugars with reactive residues at the binding sites (Houen \& Hansen 1997).

\section{Practical considerations}

1. Commercial PBS or TBS are recommended to maximize the reproducibility. The buffer should be prepared according to the manufacturer's recommendations. The commercial buffer usually makes up $5 \mathrm{~L}$ of solution.

2. The primary antibody should be diluted with TBS or PBS to an optimal concentration. These should be empirically titrated on a known positive specimen. Working antibody concentrations usually lie between $10-20 \mu \mathrm{g} / \mathrm{mL}$. Depending on the individual reagent, this concentration could vary considerably. The initial dilution can start at 1:10 with subsequent serial 1:10 dilutions, resulting in 10,100,1000, and 10,000-fold dilutions of the original antibody. Optimal staining can be obtained from this wide range of dilutions. A higher resolution for the optimal staining can be obtained through serial 1:2 dilutions of the formerly obtained wide dilution. The antibodies can be aliquoted and stored in concentrated form at -70 to $-80^{\circ} \mathrm{C}$ indefinitely. The antibodies should be thawed once and used immediately. Refreezing antibodies should be avoided. However, the manufacturer recommends that the $\mathrm{ABC}$ reagent components should be stored at $4^{\circ} \mathrm{C}$. The antibody can be thawed and diluted to a concentrated stock solution from which more diluted working solutions can be prepared. These stock solutions can be kept at $4-8^{\circ} \mathrm{C}$ for a week.

3. An antibody in either polyclonal or monoclonal format can be applied for sputum staining with distinct advantages / disadvantages. The polyclonal antibody generally provides strong signal with reasonably good specificity, but can generate some background noise. The signal strength of a monoclonal antibody depends on its qualities and affinity but its specificity for antigen binding is far better than that of the polyclonal format. The preference for a monoclonal antibody over a polyclonal antibody largely depends on the availability of a qualified antibody with matching application. The chosen antibody has to be specific with no cross reaction to other cell components. The antibody should contain a high affinity to the antigen be produced in high titer. The monoclonal antibody generally creates minimal background noise. Its high affinity can withstand multiple processing steps of staining and washing with minimal loss of the attaching antibody.

4. The incubation with $10 \%$ xenogeneic serum will mask all non-specific binding sites on the specimen. The 10-min incubation with the $10 \%$ xenogeneic serum can prevent the non-specific antibody binding. The proportion of the serum and the incubation time can be optimized to generate acceptable signal. 
5. The choice of blocking serum depends on the originating species of the secondary antibody. A universal type of blocking serum can be used if the secondary antibody has multiple host species to avoid the cross-reactivity. The pooled or universal secondary antibody can be used regardless of the originating species of the primary antibody. Proteins from other sources (e.g., milk, or casein-based solutions) can be employed as blocking agents, but they may not produce better results.

6. The specimens should be kept hydrated throughout the staining procedure. The inadvertent drying can generate nonspecific antibody binding. A chamber rack can be used to prevent the flowing of antibodies away with gravity.

7. All reagents and slides should sit at room temperature before the staining. The antibodies should be fully dissolved or reconstituted. The staining results can even be better if the antibody solutions are prepared the day before and left at $4^{\circ} \mathrm{C}$ overnight. The incubation time and temperature can be raised to optimize the reactivity. However, this might increase the background noise too. The reaction may be slightly improved without cumulative background by the incubation with primary antibody overnight at $4^{\circ} \mathrm{C}$ (Clements \& Beitz 1985).

8. Vigorous rinsing is recommended to lessen the background noise. However, direct splashing to the specimen surface with the wash stream may dislodge antibodies with low affinity. The stream should be rapidly running from one end of the slide, crossing the slide surface to the other end. The washing step is the most critical factor to lessen the background noise and could be extended if the background noise is heavily concerned. The inclusion of non-ionic detergent (i.e., $0.25 \%$ Triton X-100 or $0.1 \%$ Tween 20) may also lessen the background (Laitinen, et al. 1983, Maneechotesuwan et al. 2008). However, these detergents may interfere the charge interactions of antibody-antigen binding, resulting in decreasing reactivity. These detergents should be applied to poly-L-lysine-coated or charged slides to improve the hydrophobicity of these slides. The reaction can be strengthened through extending incubation times (60 min for primary and 45 min for the secondary or $A B C$ incubation), raising chromogen concentration to prevail over the dampening effect of the detergents. The chromogen concentration may be raised from 2-5 times. If background noise is highly concerned, a preabsorption of the slide with blocking agents may be required. The antibody may be diluted in buffer containing $2 \%$ bovine serum albumin, or secondary species serum to avoid the reaction from contaminating non-specific antibodies against a serumbased constituent.

9. The formation of $\mathrm{ABC}$ complex takes at least 30 min to be stable. Only after the $\mathrm{ABC}$ complex is stably formed can the secondary antibody be added. The complex can be kept in the refrigerator for at least $72 \mathrm{~h}$.

10. The counterstain should not be stronger than the principal reaction; otherwise the staining sites can be masked by darker counterstain.

11. Many substrates for alkaline phosphatase provide permanent straining with different color. A combination of 5-bromo-4-chloro-3-indolyl phosphate (BCIP) and nitro blue tetrazolium (NBT) yield permanent blue precipitates at the site of alkaline phosphatase, while the Fast Red TR/Naphthol AS-MX yields a permanent red precipitates.

12. The staining sensitivity can be increased through the use of multiple chromogens and multiple enzymes targeting numerous antigens. More substrate precipitation or greater color resolution improves the sensitivity. 


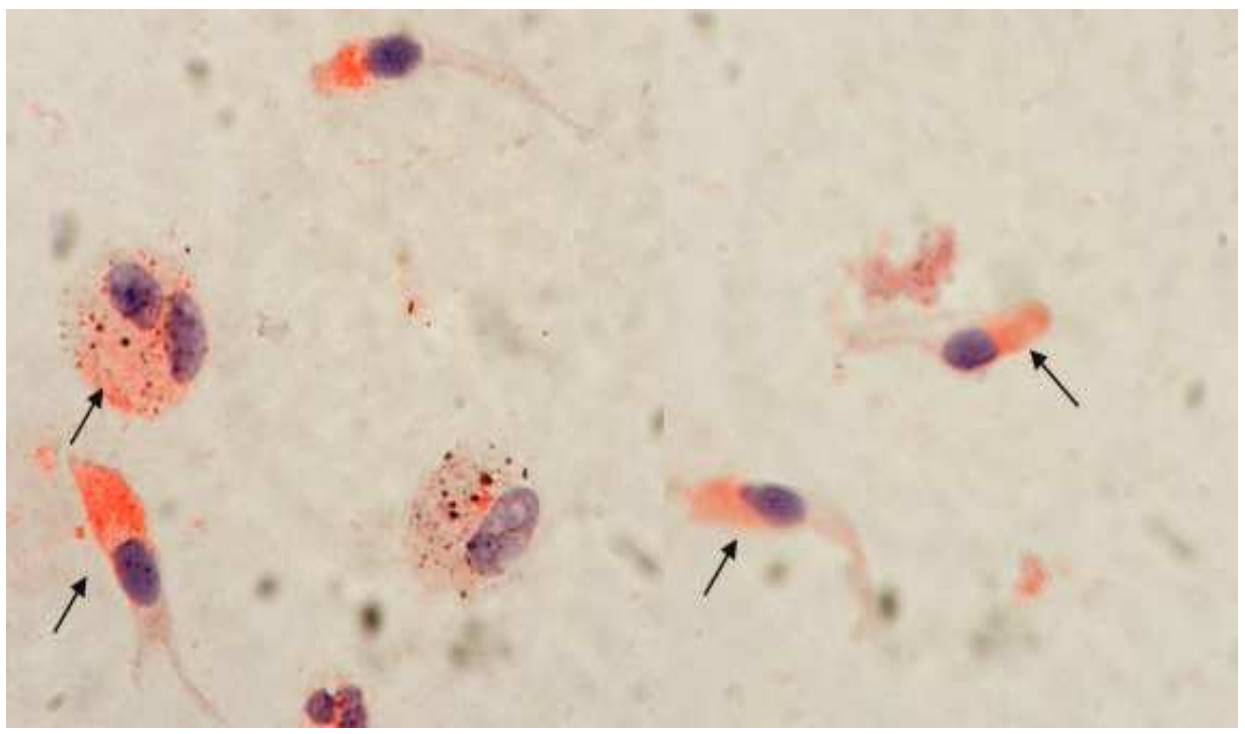

Fig. 1. The sputum cells were immunocytochemically stained for indoleamine 2, 3 dioxygenase with VECTOR® ABC-AP KIT.

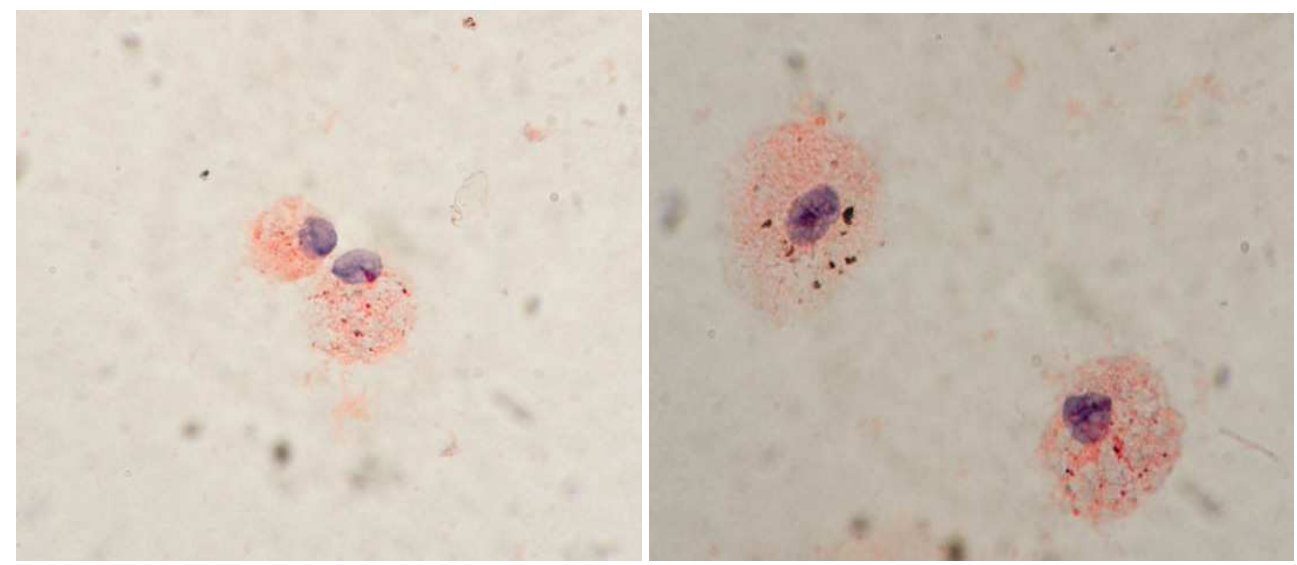

Fig. 2. The sputum cells were immunocytochemically stained for interleukin-10 with VECTOR® ABC-AP KIT.

\subsection{Prototypic procedure for immunocytochemical staining of a sputum specimen} (VECTASTAIN® ABC-AP KIT)

1. The cytospin slide will be removed from the freezer $\left(-20^{\circ} \mathrm{C}\right)$ and left at room temperature for 30-60 min.

2. The cellular spot on the slides will be encircled with the wax pen.

3. The slide will be washed once with PBS for $5 \mathrm{~min}$.

4. The washed slide will be placed horizontally in a humidified chamber. 
5. The sputum cells will be fixed with $2 \%$ paraformaldehyde (PFA) for 5 min.

6. The slide will be completely washed once with PBS to remove residual PFA for $5 \mathrm{~min}$.

7. The cell membrane will be permeabilized with $0.5 \% \mathrm{NP}-40$ diluted in PBS for $10 \mathrm{~min}$.

8. The slide will be washed once with PBS for $5 \mathrm{~min}$.

9. Nonspecific binding will be blocked with the blocking serum (normal serum) from the Vector Kit (3 drops of stock to $10 \mathrm{~mL}$ PBS with $0.05 \%$ tween-20) for $30 \mathrm{~min}$.

10. The slide will be incubated with the primary antibody pre-diluted in PBS with $0.05 \%$ tween-20 (1:100) for $1 \mathrm{~h}$.

11. The slide will be washed thrice with PBS containing $0.05 \%$ tween- 20 for 5 min.

12. Incubate the slide with the biotinylated secondary antibody pre-diluted in PBS with $0.05 \%$ tween-20 (add 1 drop of stock to $10 \mathrm{~mL}$ PBS with $0.05 \%$ tween-20) for $45 \mathrm{~min}$.

13. The VECTASTAIN ${ }^{\circledR}$ ABC-AP Reagent will be prepared by adding exactly 2 drops of Reagent A to $10 \mathrm{~mL}$ PBS with $0.05 \%$ tween-20, followed by adding 2 drops of Reagent $B$. The mixture will be immediately mixed and left at room temperature for at least 30 min before the next step.

14. The slide will be washed thrice with PBS containing $0.05 \%$ tween-20 for 5 min each.

15. The slide will be incubated with VECTASTAIN ${ }_{\circledast}$ ABC-AP Reagent for $30 \mathrm{~min}$.

16. The slide will be washed once with PBS without tween-20 for $5 \mathrm{~min}$.

17. The Vector ${ }^{\circledR}$ Red substrate working solution will be prepared immediately before use in test tube by adding 2 drops of Reagent 1 to $5 \mathrm{~mL} 100 \mathrm{mM}$ Tris- $\mathrm{HCl}$ (pH 8.2-8.5) followed by a thoroughly mixing. The mixture will be subsequently reconstituted with 2 drops of Reagent 2 and 2 drops of Reagent 3 sequentially with a thoroughly mixing after each reagent addition.

\section{References}

Bacci, E.; Bartoli, M.; Carnevali, S. \& Al., E. (1999). Eosinophil cationic protein (ECP) and histamine levels in induced sputum are not affected by hypertonic saline inhalation. Eur Respir J, vol. 14:Suppl. 30, p. 24.

Bacci, E.; Cianchetti, S.; Ruocco, L.; Bartoli, M.L.; Carnevali, S.; Dente, F.L.; Di Franco, A.; Giannini, D.; Macchioni, P.; Vagaggini, B.; Morelli, M.C. \& Paggiaro, P.L. (1998). Comparison between eosinophilic markers in induced sputum and blood in asthmatic patients. Clin Exp Allergy, vol. 28, no. 10, pp. 1237-43, ISSN 0954-7894

Bratthauer, G.L. (2010). The avidin-biotin complex (ABC) method and other avidin-biotin binding methods. Methods in molecular biology, vol. 588, pp. 257-70, ISSN 1940-6029

Cianchetti, S.; Bacci, E.; Ruocco, L.; Bartoli, M.L.; Carnevali, S.; Dente, F.L.; Di Franco, A.;

Giannini, D.; Scuotri, L.; Vagaggini, B. \& Paggiaro, P.L. (1999). Salbutamol pretreatment does not change eosinophil percentage and eosinophilic cationic protein concentration in hypertonic saline-induced sputum in asthmatic subjects. Clin Exp Allergy, vol. 29, no. 5, pp. 712-8, ISSN 0954-7894

Cleland,W.W. (1964). Dithiothreitol, a New Protective Reagent for Sh Groups. Biochemistry, vol. 3, pp. 480-2, ISSN 0006-2960

Clements, J.R. \& Beitz, A.J. (1985). The effects of different pretreatment conditions and fixation regimes on serotonin immunoreactivity: a quantitative light microscopic study. The journal of histochemistry and cytochemistry : official journal of the Histochemistry Society, vol. 33, no. 8, pp. 778-84, ISSN 0022-1554 
De La Fuente, P.T.; Romagnoli, M.; Godard, P.; Bousquet, J. \& Chanez, P. (1998). Safety of inducing sputum in patients with asthma of varying severity. Am J Respir Crit Care Med, vol. 157, no. 4 Pt 1, pp. 1127-30, ISSN 1073-449X

Efthimiadis, A.; Pizzichini, M. \& Pizzichini, E.E., Al. (1995). The influence of cell viability and squamous cell contamination on the reliability of sputum differential cell counts. Am J Respir Crit Care Med, vol. 151,

Efthimiadis, A.; Popov, T.; Kolendowicz, R.; Dolovich, J. \& Hargreave, F.E. (1996). Increasing the yield of sputum cells for examination. Am J Respir Crit Care Med, vol. 149, p. A949

Efthimiadis, A.; Spanevello, A.; Hamid, Q.; Kelly, M.M.; Linden, M.; Louis, R.; Pizzichini, M.M.; Pizzichini, E.; Ronchi, C.; Van Overvel, F. \& Djukanovic, R. (2002). Methods of sputum processing for cell counts, immunocytochemistry and in situ hybridisation. Eur Respir J Suppl, vol. 37, pp. 19s-23s, ISSN 0904-1850

Efthimiadis, A.; Weston, S.; Carruthers, S.; Hussack, P. \& Hargreave, F. (2000). Induce sputum: effect of filtration on the total and differential cell counts. Am J Respir Crit Care Med, vol. 161, p. A853,

Fahy, J.V.; Liu, J.; Wong, H. \& Boushey, H.A. (1993). Cellular and biochemical analysis of induced sputum from asthmatic and from healthy subjects. Am Rev Respir Dis, vol. 147, no. 5, pp. 1126-31, ISSN 0003-0805

Fahy, J.V.; Wong, H.; Liu, J. \& Boushey, H.A. (1995). Comparison of samples collected by sputum induction and bronchoscopy from asthmatic and healthy subjects. Am J Respir Crit Care Med, vol. 152, no. 1, pp. 53-8, ISSN 1073-449X

Fleury-Feith, J.; Escudier, E.; Pocholle, M.J.; Carre, C. \& Bernaudin, J.F. (1987). The effects of cytocentrifugation on differential cell counts in samples obtained by bronchoalveolar lavage. Acta Cytol, vol. 31, no. 5, pp. 606-10, ISSN 0001-5547

Gershman, N.H.; Liu, H.; Wong, H.H.; Liu, J.T. \& Fahy, J.V. (1999). Fractional analysis of sequential induced sputum samples during sputum induction: evidence that different lung compartments are sampled at different time points. J Allergy Clin Immunol, vol. 104, no. 2 Pt 1, pp. 322-8, ISSN 0091-6749

Gershman, N.H.; Wong, H.H.; Liu, J.T.; Mahlmeister, M.J. \& Fahy, J.V. (1996). Comparison of two methods of collecting induced sputum in asthmatic subjects. Eur Respir J, vol. 9, no. 12, pp. 2448-53, ISSN 0903-1936

Gillitzer, R.; Berger, R. \& Moll, H. (1990). A reliable method for simultaneous demonstration of two antigens using a novel combination of immunogold-silver staining and immunoenzymatic labeling. The journal of histochemistry and cytochemistry : official journal of the Histochemistry Society, vol. 38, no. 3, pp. 307-13, ISSN 0022-1554

Goldenthal, K.L.; Hedman, K.; Chen, J.W.; August, J.T. \& Willingham, M.C. (1985a). Postfixation detergent treatment for immunofluorescence suppresses localization of some integral membrane proteins. The journal of histochemistry and cytochemistry : official journal of the Histochemistry Society, vol. 33, no. 8, pp. 813-20, ISSN 0022-1554

Goldenthal, K.L.; Hedman, K.; Chen, J.W.; August, J.T. \& Willingham, M.C. (1985b). Postfixation detergent treatment for immunofluorescence suppresses localization of some integral membrane proteins. J Histochem Cytochem, vol. 33, no. 8, pp. 813-20, ISSN 0022-1554 
Gravelyn, T.R.; Pan, P.M. \& Eschenbacher, W.L. (1988). Mediator release in an isolated airway segment in subjects with asthma. Am Rev Respir Dis, vol. 137, no. 3, pp. 6416, ISSN 0003-0805

Hall, P.A.; Stearn, P.M.; Butler, M.G. \& D'ardenne, A.J. (1987). Acetone/periodate-lysineparaformaldehyde (PLP) fixation and improved morphology of cryostat sections for immunohistochemistry. Histopathology, vol. 11, no. 1, pp. 93-101, ISSN 03090167

Hansel, T.T.; Braunstein, J.B.; Walker, C.; Blaser, K.; Bruijnzeel, P.L.; Virchow, J.C., Jr. \& Virchow, C., Sr. (1991). Sputum eosinophils from asthmatics express ICAM-1 and HLA-DR. Clin Exp Immunol, vol. 86, no. 2, pp. 271-7, ISSN 0009-9104

Holz, O.; Jorres, R.A.; Koschyk, S.; Speckin, P.; Welker, L. \& Magnussen, H. (1998a). Changes in sputum composition during sputum induction in healthy and asthmatic subjects. Clin Exp Allergy, vol. 28, no. 3, pp. 284-92, ISSN 0954-7894

Holz, O.; Richter, K.; Jorres, R.A.; Speckin, P.; Mucke, M. \& Magnussen, H. (1998b). Changes in sputum composition between two inductions performed on consecutive days. Thorax, vol. 53, no. 2, pp. 83-6, ISSN 0040-6376

Houen, G. \& Hansen, K. (1997). Interference of sugars with the binding of biotin to streptavidin and avidin. Journal of immunological methods, vol. 210, no. 2, pp. 115-23, ISSN 0022-1759

Iredale, M.J.; Wanklyn, S.A.; Phillips, I.P.; Krausz, T. \& Ind, P.W. (1994). Non-invasive assessment of bronchial inflammation in asthma: no correlation between eosinophilia of induced sputum and bronchial responsiveness to inhaled hypertonic saline. Clin Exp Allergy, vol. 24, no. 10, pp. 940-5, ISSN 0954-7894

Jatakanon, A.; Lim, S.; Chung, K.F. \& Barnes, P.J. (1998). An inhaled steroid improves markers of airway inflammation in patients with mild asthma. Eur Respir J, vol. 12, no. 5, pp. 1084-8, ISSN 0903-1936

Kidney, J.C.; Wong, A.G.; Efthimiadis, A.; Morris, M.M.; Sears, M.R.; Dolovich, J. \& Hargreave, F.E. (1996). Elevated B cells in sputum of asthmatics. Close correlation with eosinophils. Am J Respir Crit Care Med, vol. 153, no. 2, pp. 540-4, ISSN 1073$449 X$

Laitinen, L.A.; Laitinen, A.; Panula, P.A.; Partanen, M.; Tervo, K. \& Tervo, T. (1983). Immunohistochemical demonstration of substance $\mathrm{P}$ in the lower respiratory tract of the rabbit and not of man. Thorax, vol. 38, no. 7, pp. 531-6, ISSN 0040-6376

Louis, R.; Shute, J.; Goldring, K.; Perks, B.; Lau, L.C.; Radermecker, M. \& Djukanovic, R. (1999). The effect of processing on inflammatory markers in induced sputum. Eur Respir J, vol. 13, no. 3, pp. 660-7, ISSN 0903-1936

Maestrelli, P.; Calcagni, P.G.; Saetta, M.; Di Stefano, A.; Hosselet, J.J.; Santonastaso, A.; Fabbri, L.M. \& Mapp, C.E. (1994). Sputum eosinophilia after asthmatic responses induced by isocyanates in sensitized subjects. Clin Exp Allergy, vol. 24, no. 1, pp. 2934, ISSN 0954-7894

Maestrelli, P.; Saetta, M.; Di Stefano, A.; Calcagni, P.G.; Turato, G.; Ruggieri, M.P.; Roggeri, A.; Mapp, C.E. \& Fabbri, L.M. (1995). Comparison of leukocyte counts in sputum, bronchial biopsies, and bronchoalveolar lavage. Am J Respir Crit Care Med, vol. 152, no. 6 Pt 1, pp. 1926-31, ISSN 1073-449X

Makker, H.K. \& Holgate, S.T. (1993). The contribution of neurogenic reflexes to hypertonic saline-induced bronchoconstriction in asthma. J Allergy Clin Immunol, vol. 92, no. 1 Pt 1, pp. 82-8, ISSN 0091-6749 
Maneechotesuwan, K.; Ekjiratrakul, W.; Kasetsinsombat, K.; Wongkajornsilp, A. \& Barnes, P.J. (2010). Statins enhance the anti-inflammatory effects of inhaled corticosteroids in asthmatic patients through increased induction of indoleamine 2, 3-dioxygenase. J Allergy Clin Immunol, vol. 126, no. 4, pp. 754-762 e1, ISSN 1097-6825

Maneechotesuwan, K.; Supawita, S.; Kasetsinsombat, K.; Wongkajornsilp, A. \& Barnes, P.J. (2008). Sputum indoleamine-2, 3-dioxygenase activity is increased in asthmatic airways by using inhaled corticosteroids. J Allergy Clin Immunol, vol. 121, no. 1, pp. 43-50, ISSN 1097-6825

Mclean, I.W. \& Nakane, P.K. (1974). Periodate-lysine-paraformaldehyde fixative. A new fixation for immunoelectron microscopy. J Histochem Cytochem, vol. 22, no. 12, pp. 1077-83, ISSN 0022-1554

Metso, T.; Haahtela, T. \& Seveus, L. (2002). Identification of intracellular markers in induced sputum and bronchoalveolar lavage samples in patients with respiratory disorders and healthy persons. Respir Med, vol. 96, no. 11, pp. 918-26, ISSN 0954-6111

Mordelet-Dambrine, M.; Arnoux, A.; Stanislas-Leguern, G.; Sandron, D.; Chretien, J. \& Huchon, G. (1984). Processing of lung lavage fluid causes variability in bronchoalveolar cell count. Am Rev Respir Dis, vol. 130, no. 2, pp. 305-6, ISSN 00030805

Nightingale, J.A.; Rogers, D.F. \& Barnes, P.J. (1998). Effect of repeated sputum induction on cell counts in normal volunteers. Thorax, vol. 53, no. 2, pp. 87-90, ISSN 0040-6376

Paggiaro, P.L.; Chanez, P.; Holz, O.; Ind, P.W.; Djukanovic, R.; Maestrelli, P. \& Sterk, P.J. (2002). Sputum induction. Eur Respir J Suppl, vol. 37, pp. 3s-8s, ISSN 0904-1850

Parameswaran, K.; Anvari, M.; Efthimiadis, A.; Kamada, D.; Hargreave, F.E. \& Allen, C.J. (2000). Lipid-laden macrophages in induced sputum are a marker of oropharyngeal reflux and possible gastric aspiration. Eur Respir J, vol. 16, no. 6, pp. 1119-22, ISSN 0903-1936

Peleman, R.A.; Rytila, P.H.; Kips, J.C.; Joos, G.F. \& Pauwels, R.A. (1999). The cellular composition of induced sputum in chronic obstructive pulmonary disease. Eur Respir J, vol. 13, no. 4, pp. 839-43, ISSN 0903-1936

Pieri, L.; Sassoli, C.; Romagnoli, P. \& Domenici, L. (2002). Use of periodate-lysineparaformaldehyde for the fixation of multiple antigens in human skin biopsies. Eur J Histochem, vol. 46, no. 4, pp. 365-75, ISSN 1121-760X

Pin, I.; Gibson, P.G.; Kolendowicz, R.; Girgis-Gabardo, A.; Denburg, J.A.; Hargreave, F.E. \& Dolovich, J. (1992). Use of induced sputum cell counts to investigate airway inflammation in asthma. Thorax, vol. 47, no. 1, pp. 25-9, ISSN 0040-6376

Pizzichini, E.; Pizzichini, M.M.; Efthimiadis, A.; Evans, S.; Morris, M.M.; Squillace, D.; Gleich, G.J.; Dolovich, J. \& Hargreave, F.E. (1996a). Indices of airway inflammation in induced sputum: reproducibility and validity of cell and fluid-phase measurements. Am J Respir Crit Care Med, vol. 154, no. 2 Pt 1, pp. 308-17, ISSN 1073449X

Pizzichini, E.; Pizzichini, M.M.; Efthimiadis, A.; Hargreave, F.E. \& Dolovich, J. (1996b). Measurement of inflammatory indices in induced sputum: effects of selection of sputum to minimize salivary contamination. Eur Respir J, vol. 9, no. 6, pp. 1174-80, ISSN 0903-1936

Pizzichini, E.; Pizzichini, M.M.; Kidney, J.C.; Efthimiadis, A.; Hussack, P.; Popov, T.; Cox, G.; Dolovich, J.; O'byrne, P. \& Hargreave, F.E. (1998). Induced sputum, 
bronchoalveolar lavage and blood from mild asthmatics: inflammatory cells, lymphocyte subsets and soluble markers compared. Eur Respir J, vol. 11, no. 4, pp. 828-34, ISSN 0903-1936

Popov, T.; Gottschalk, R.; Kolendowicz, R.; Dolovich, J.; Powers, P. \& Hargreave, F.E. (1994). The evaluation of a cell dispersion method of sputum examination. Clin Exp Allergy, vol. 24, no. 8, pp. 778-83, ISSN 0954-7894

Popov, T.A.; Pizzichini, M.M.; Pizzichini, E.; Kolendowicz, R.; Punthakee, Z.; Dolovich, J. \& Hargreave, F.E. (1995). Some technical factors influencing the induction of sputum for cell analysis. Eur Respir J, vol. 8, no. 4, pp. 559-65, ISSN 0903-1936

Purokivi, M.; Randell, J.; Hirvonen, M.R. \& Tukiainen, H. (2000). Reproducibility of measurements of exhaled NO, and cell count and cytokine concentrations in induced sputum. Eur Respir J, vol. 16, no. 2, pp. 242-6, ISSN 0903-1936

Rankin, J.A.; Marcy, T.; Rochester, C.L.; Sussman, J.; Smith, S.; Buckley, P. \& Lee, D. (1992). Human airway macrophages. A technique for their retrieval and a descriptive comparison with alveolar macrophages. Am Rev Respir Dis, vol. 145, no. 4 Pt 1, pp. 928-33, ISSN 0003-0805

Rantala, I.; Maki, M.; Laasonen, A. \& Visakorpi, J.K. (1985). Periodate-lysineparaformaldehyde as fixative for the study of duodenal mucosa. Morphologic and immunohistochemical results at light and electron microscopic levels. Acta Pathol Microbiol Immunol Scand A, vol. 93, no. 4, pp. 165-73, ISSN 0108-0164

Rerecich, T.J.; Gauvreau, G.M.; Kelly, M.M.; Hargreave, F.E. \& O’ Byrne, P.M. (1999). Optimization of sputum fluid phase measurements. Am J Respir Crit Care Med, vol. 159, p. A849,

Richter, K.; Holz, O.; Jorres, R.A.; Mucke, M. \& Magnussen, H. (1999). Sequentially induced sputum in patients with asthma or chronic obstructive pulmonary disease. Eur Respir J, vol. 14, no. 3, pp. 697-701, ISSN 0903-1936

Seeman, P.; Cheng, D. \& Iles, G.H. (1973). Structure of membrane holes in osmotic and saponin hemolysis. The Journal of cell biology, vol. 56, no. 2, pp. 519-27, ISSN 00219525

Smith, C.M. \& Anderson, S.D. (1989). Inhalation provocation tests using nonisotonic aerosols. J Allergy Clin Immunol, vol. 84, no. 5 Pt 1, pp. 781-90, ISSN 0091-6749

Spanevello, A.; Beghe, B.; Bianchi, A.; Migliori, G.B.; Ambrosetti, M.; Neri, M. \& Ind, P.W. (1998). Comparison of two methods of processing induced sputum: selected versus entire sputum. Am J Respir Crit Care Med, vol. 157, no. 2, pp. 665-8, ISSN 1073-449X

St-Laurent, J.; Boulay, M.E.; Prince, P.; Bissonnette, E. \& Boulet, L.P. (2006). Comparison of cell fixation methods of induced sputum specimens: an immunocytochemical analysis. J Immunol Methods, vol. 308, no. 1-2, pp. 36-42, ISSN 0022-1759

Tockman, M.S.; Qiao, Y.; Li, L.; Zhao, G.Z.; Sharma, R.; Cavenaugh, L.L. \& Erozan, Y.S. (1995). Safe separation of sputum cells from mucoid glycoprotein. Acta cytologica, vol. 39, no. 6, pp. 1128-36, ISSN 0001-5547

Van Overveld, F.J.; Demkow, U.; Gorecka, D.; Skopinska-Rozewska, E.; De Backer, W.A. \& Zielinski, J. (2005). Effects of homogenization of induced sputum by dithiothreitol on polymorphonuclear cells. Journal of physiology and pharmacology : an official journal of the Polish Physiological Society, vol. 56 Suppl 4, pp. 143-54, ISSN 1899-1505 
Vatrella, A.; Perna, F.; Pelaia, G.; Parrella, R.; Maselli, R.; Marsico, S.A. \& Calabrese, C. (2010). T cell activation state in the induced sputum of asthmatics treated with budesonide. Int J Immunopathol Pharmacol, vol. 23, no. 3, pp. 745-53, ISSN 0394-6320

Voynow, J.A. \& Rubin, B.K. (2009). Mucins, mucus, and sputum. Chest, vol. 135, no. 2, pp. 505-12, ISSN 1931-3543

Wong, H.H. \& Fahy, J.V. (1997). Safety of one method of sputum induction in asthmatic subjects. Am J Respir Crit Care Med, vol. 156, no. 1, pp. 299-303, ISSN 1073-449X 


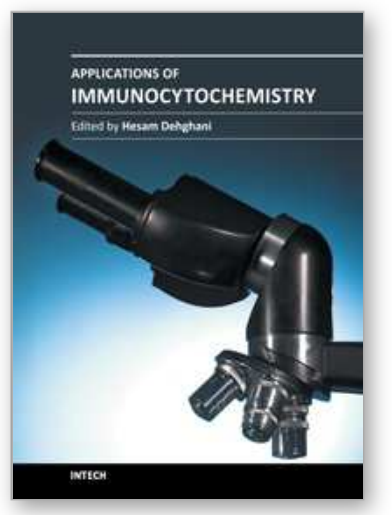

\author{
Applications of Immunocytochemistry \\ Edited by Dr. Hesam Dehghani
}

ISBN 978-953-51-0229-8

Hard cover, 320 pages

Publisher InTech

Published online 09, March, 2012

Published in print edition March, 2012

Immunocytochemistry is classically defined as a procedure to detect antigens in cellular contexts using antibodies. However, over the years many aspects of this procedure have evolved within a plethora of experimental setups. There are different ways to prepare a given specimen, different kinds of antibodies to apply, different techniques for imaging, and different methods of analyzing the data. In this book, various ways of performing each individual step of immunocytochemistry in different cellular contexts are exemplified and discussed. Applications of Immunocytochemistry offers technical and background information on different steps of immunocytochemistry and presents the application of this technique and its adaptations in cell lines, neural tissue, pancreatic tissue, sputum cells, sperm cells, preimplantation embryo, arabidopsis, fish gonads, and Leishmania.

\title{
How to reference
}

In order to correctly reference this scholarly work, feel free to copy and paste the following:

Kittipong Maneechotesuwan and Adisak Wongkajornsilp (2012). Application of Immunocytochemistry to Sputum Cells to Investigate Molecular Mechanisms of Airway Inflammation, Applications of Immunocytochemistry, Dr. Hesam Dehghani (Ed.), ISBN: 978-953-51-0229-8, InTech, Available from: http://www.intechopen.com/books/applications-of-immunocytochemistry/application-of-immunocytochemistryto-sputum-cells-to-investigate-molecular-mechanisms-of-airway-inf

\section{INTECH}

open science | open minds

\section{InTech Europe}

University Campus STeP Ri

Slavka Krautzeka 83/A

51000 Rijeka, Croatia

Phone: +385 (51) 770447

Fax: +385 (51) 686166

www.intechopen.com

\section{InTech China}

Unit 405, Office Block, Hotel Equatorial Shanghai

No.65, Yan An Road (West), Shanghai, 200040, China

中国上海市延安西路65号上海国际贵都大饭店办公楼 405 单元

Phone: +86-21-62489820

Fax: $+86-21-62489821$ 
(C) 2012 The Author(s). Licensee IntechOpen. This is an open access article distributed under the terms of the Creative Commons Attribution 3.0 License, which permits unrestricted use, distribution, and reproduction in any medium, provided the original work is properly cited. 